\title{
Article/Artigo
}

\section{Investigation of measles IgM-seropositive cases of febrile rash illnesses in the absence of documented measles virus transmission, State of São Paulo, Brazil, 2000-2004}

\author{
Investigação dos casos de doenças febris exantemáticas com IgM reagente contra o sarampo na \\ ausência de transmissão documentada do vírus do sarampo, Estado de São Paulo, 2000-2004

\section{Flávia Helena Ciccone', Telma Regina Marques Pinto Carvalhanas ${ }^{2}$, Ana Maria Sardinha Afonso ${ }^{3}$, Brendan Flannery ${ }^{4}$ and Eliseu Alves Waldman ${ }^{1}$}

\begin{abstract}
Introduction: To review measles IgM-positive cases of febrile rash illnesses in the State of São Paulo, Brazil, over the five-year period following interruption of measles virus transmission. Methods: We reviewed 463 measles IgM-positive cases of febrile rash illness in the State of São Paulo, from 2000 to 2004. Individuals vaccinated against measles $\leq 56$ days prior to specimen collection were considered to be exposed to the vaccine. Serum from the acute and convalescent phases was tested for evidence of measles, rubella, parvovirus B19 and human herpes virus- 6 infection. In the absence of seroconversion to measles immunoglobulin-G, measles IgM-positive cases were considered false positives in individuals with evidence of other viral infections. Results: Among the 463 individuals with febrile rash illness who tested positive for measles IgM antibodies during the period, 297 (64\%) were classified as exposed to the vaccine. Among the 166 cases that were not exposed to the vaccine, $109(66 \%)$ were considered false positives based on the absence of seroconversion, among which 21 (13\%) had evidence of rubella virus infection, $49(30 \%)$ parvovirus B19 and 28 (17\%) human herpes virus-6 infection. Conclusions: Following the interruption of measles virus transmission, thorough investigation of measles IgM-positive cases is required, especially among cases not exposed to the vaccine. Laboratory testing for etiologies of febrile rash illness aids interpretation of these cases.

Key-words: Measles. Syndromic surveillance. Rash illness.
\end{abstract}

\section{RESUMO}

Introdução: Revisar os casos de doenças febris exantemáticas com IgM reagente contra o sarampo, no Estado de São Paulo, Brasil, durante os cinco anos seguidos a interrupção da transmissão do vírus do sarampo. Métodos: Nós revisamos 463 casos de doenças febris exantemáticas com IgM reagente contra o sarampo, no Estado de São Paulo, Brasil, de 2000 a 2004. Indivíduos vacinados contra o sarampo 56 dias antes da coleta de amostra foram considerados expostos à vacina. Soros da fase aguda e de convalescença foram testados para a evidência de infecção de sarampo, rubéola, parvovírus B19 e herpes vírus 6. Na ausência de soroconversão para imunoglobulina G contra o sarampo, casos com IgM reagente contra o sarampo foram considerados falsos positivos em pessoas com evidência de outras infecções virais. Resultados: Entre as 463 pessoas com doenças febris exantemáticas que testaram positivo para anticorpos IgM contra o sarampo durante o período, 297 (64\%) pessoas foram classificadas como expostas à vacina. Entre os 166 casos não expostos à vacina, 109 (66\%) foram considerados falsos positivos baseado na ausência de soroconversão, dos quais 21 (13\%) tiveram evidência de infecção por vírus da rubéola, 49 (30\%) parvovírus B19 e 28 (17\%) infecção por herpes vírus humano 6. Conclusões: Após a interrupção da transmissão do vírus do sarampo é necessária exaustiva investigação dos casos com IgM reagente contra o sarampo, especialmente dos casos não expostos à vacina. Testes laboratoriais para etiologias das doenças febris exantemáticas ajudam na interpretação destes casos.

Palavras-chaves: Sarampo. Vigilância por síndrome. Doença exantemática.

1. School of Public Health, University of São Paulo, São Paulo, SP. 2. Professor Alexandre Vranjac, Center for Epidemiologic Surveillance, Communicable Diseases Control, São Paulo State Health Department, São Paulo, SP. 3. Adolfo Lutz Institute, São Paulo State Health Department, São Paulo State Health, Department Adolfo Lutz Institute, São Paulo, SP. 4. Pan American Health Organization, Brasilia, DF. Address to: Dr. Eliseu Alves Waldman. Faculdade de Saúde Pública/USP. Av. Dr. Arnaldo 715, Cerqueira César, 01246-904 São Paulo, SP.

Tel: 5511 3061-7109

e-mail: eawaldma@usp.br

Received in 05/11/2009

Accepted in 28/01/2010

\section{INTRODUCTION}

Brazil interrupted endemic measles virus transmission in $2000^{1}$. Measles elimination in Brazil followed the Pan-American Health Organization (PAHO) regional strategy ${ }^{2}$. High routine coverage and follow-up campaigns have continued since 2000 to prevent sustained transmission of measles virus following importations ${ }^{1,3}$ :

Brazil maintains surveillance for febrile rash illnesses through collection of acute phase blood samples for measles and rubella serological tests. As recommended by $\mathrm{PAHO}^{3,4}$, individuals with febrile rash illness and positive serological tests for measles immunoglobulin M (IgM) antibodies are treated as confirmed measles cases, for prompt implementation of control strategies. However, in the absence of measles virus transmission, individuals with febrile rash illnesses may test positive for IgM antibodies as a result of recent measles vaccination or cross-reactivity of serological assays with other etiologies of rash illness ${ }^{5}$. Guidance for interpretation of positive measles IgM in settings of little or no measles virus transmission has been published $^{4-7}$, but there are few data from surveillance systems on the classification of measles IgM-positive reactions in practice.

The objective of this study was to review the possible causes of measles IgM-seropositive episodes of febrile rash illnesses in the State of São Paulo, Brazil, following interruption of endemic measles virus transmission.

\section{METHODS}

\section{Study population}

The State of São Paulo, Brazil, has approximately 40 million inhabitants, with 18 million residents in São Paulo metropolitan area. Measles vaccine has been used since 1968. During 2000-2003, the recommended vaccination schedule included 
monovalent measles vaccine at nine months of age and measlesmumps-rubella (MMR) vaccine at 15 months of age. In 2003, the schedule included a single dose of MMR at 12 months of age. In 2004, a recommendation for a second dose of MMR among children 4 to 6 years of age was added to the immunization calendar. Between 2000 and 2004, approximately 700,000 doses of measles vaccines were administered annually in routine immunizations (greater than $95 \%$ vaccination coverage with a first dose of measles vaccine). In addition, in 2000 and 2004 , more than $92 \%$ of children $1-4$ years of age were vaccinated during statewide measles follow-up campaigns with over 5.2 million children vaccinated. Mass vaccination of women of childbearing age was conducted in 2001, with over 4.4 million doses of measles-rubella (MR) vaccine administered ( $91 \%$ vaccination coverage).

\section{Syndromic surveillance for febrile rash illness}

Integrated measles/rubella surveillance has been conducted in the State of São Paulo since 1992. Notification of suspect cases of measles and rubella is mandatory, with immediate reporting to epidemiological surveillance officers in municipal and regional health departments. The surveillance case definition for suspected measles is a person presenting with fever, rash and either cough, coryza or conjunctivitis. For enhanced surveillance, the suspected measles case definition includes specific clinical symptoms: fever for more than two days prior to rash onset and presence of rash for at least three days. The case definition for suspected rubella is a person presenting with fever, rash and lymphadenopathy. Blood specimens for serological testing are collected at the first contact with suspected cases. The protocol requires investigation of suspected cases within 48 hours of the report. Surveillance officers collect clinical and laboratory information, interview case patients, complete notification forms, actively search for secondary cases and vaccinate close contacts. Immunization histories are recorded from vaccination cards; only documented doses of measles vaccines are recorded.

Measles IgM-seropositive episodes require additional case investigation and vaccination of contacts ${ }^{1,3}$. In 2001, enhanced surveillance to verify interruption of endemic measles transmission included collection of whole blood and urine for virus isolation from suspected measles cases with specific clinical symptoms Beginning in 2002, investigation of measles IgM-positive episodes in vaccine-unexposed individuals included collection of a second blood specimen for comparison of measles immunoglobulin $\mathrm{G}$ ( $\mathrm{IgG}$ ) antibody titers in serum pairs.

\section{Laboratory methods}

Measles and rubella serological tests were performed in nine regional laboratories of the Adolfo Lutz Institute. Measles IgM and IgG serological tests were performed using commercial indirect enzyme-linked immunosorbent assays (ELISA) (Dade Behring, Marburg, Germany) and/or measles IgM-capture ELISA (provided by the US Centers for Disease Control and Prevention [CDC] $)^{8,9}$. Measles IgG concentrations were standardized to International Units per $\mathrm{ml}$ using an internal reference, in accordance with the manufacturer's instructions. Rubella IgM serological tests were performed using commercial ELISA kits (Dade Behring, Marburg, Germany) or IgM-capture ELISA (Rubenostika II, Organon Teknika, Boxtel, Netherlands). Rubella IgM-seronegative episodes were tested for measles IgM antibodies and vice versa ${ }^{10}$. Suspected cases that were negative for both measles and rubella IgM antibodies were discarded based on laboratory criteria. In measles IgM-positive samples, additional laboratory tests were conducted to investigate possible alternative etiologies of rash illness, especially in cases without recent vaccination. Samples were tested for human parvovirus B19 infection using a commercial IgM-capture ELISA (Biotrin, Dublin, Ireland) or the polymerase chain reaction (PCR) ${ }^{11}$ and for human herpesvirus- 6 infection using immunofluorescence (Biotrin, Dublin, Ireland) or $\mathrm{PCR}^{12}$. Testing for dengue virus (EIA, PanBio), Epstein-Barr virus (ELISA, Biomérieux, Boxtel, Netherlands) or varicella virus (ELISA, Dade Behring) was based on clinical suspicion.

\section{Classification of measles IgM-seropositive cases}

Individuals vaccinated against measles $\leq 56$ days prior to specimen collection were considered to be vaccine-exposed, regardless of the date of symptom onset ${ }^{13}$. Episodes for which serum pairs demonstrated no seroconversion (from measles IgG seronegative to $\mathrm{IgG}$ positive) were discarded as non-measles. Presence of rubella IgM antibodies in individuals without recent vaccination against rubella or with an epidemiological link to a confirmed rubella case were considered to be evidence of rubella virus infection. A positive PCR reaction or serological assay was considered to be evidence of parvovirus B19 or human herpesvirus-6 (HHV-6) infection.

\section{Statistical analysis}

Data were double-entered in the Epi-Info software (version 6.04d, Centers for Disease Control and Prevention, Atlanta, GA, USA) and analyzed using the Statistical Package for the Social Sciences (SPSS, release 15, SPSS Inc, Chicago, IL, USA). The spatial and temporal distribution of measles IgM-positive cases was examined according to the epidemiological week of symptom onset and place of residence, in terms of the administrative district for the city of São Paulo or municipality and administrative health region (analogous to counties) for the rest of the state.

\section{Ethical}

This study was approved by the Ethics Research Committee of the School of Public Health of the University of São Paulo.

\section{RESULTS}

Between 2000 and 2004, 5,326 suspected measles cases and 36,977 suspected rubella cases were notified to the State of São Paulo Health Department. Among these 42,303 notifications of suspected measles or rubella, the investigations began within two days of notification in 39,342 (93\%) cases and within eight days of rash onset in 33,419 (79\%) cases. The measles notification rate declined from 5.6 to 1.2 suspected episodes per 100,000 population over this five-year period, while the rubella notification rate declined from 31.4 per 100,000 during a rubella epidemic in 2000 , to 11.6 per 100,000 during 2003-2004 (Figure 1).

From 2000-2004, serum specimens were tested in relation to 38,913 (92\%) of the 42,303 suspected measles or rubella episodes. There were 5,369 confirmed rubella episodes and 16 confirmed measles episodes ( 14 in 2000, one in 2001 and one in 2002). Of the confirmed measles episodes in 2000, 10 were laboratory-confirmed based on measles IgM antibodies in acute phase serum and were included in this analysis; of these, nine were vaccine-exposed. The confirmed measles cases in 2001 and 2002 were imported from Japan ${ }^{1}$. In 2001, the measles virus was not isolated from specimens in any of the 41 suspected measles cases with specific clinical symptoms. From 20002004 , the annual rate of laboratory-discarded suspected measles cases averaged 2.5 episodes per 100,000 population (range 1.1 to 5.5).

Among the 38,913 serum specimens tested, 463 episodes (1\%) tested positive for measles-specific IgM antibody in the initial serum 


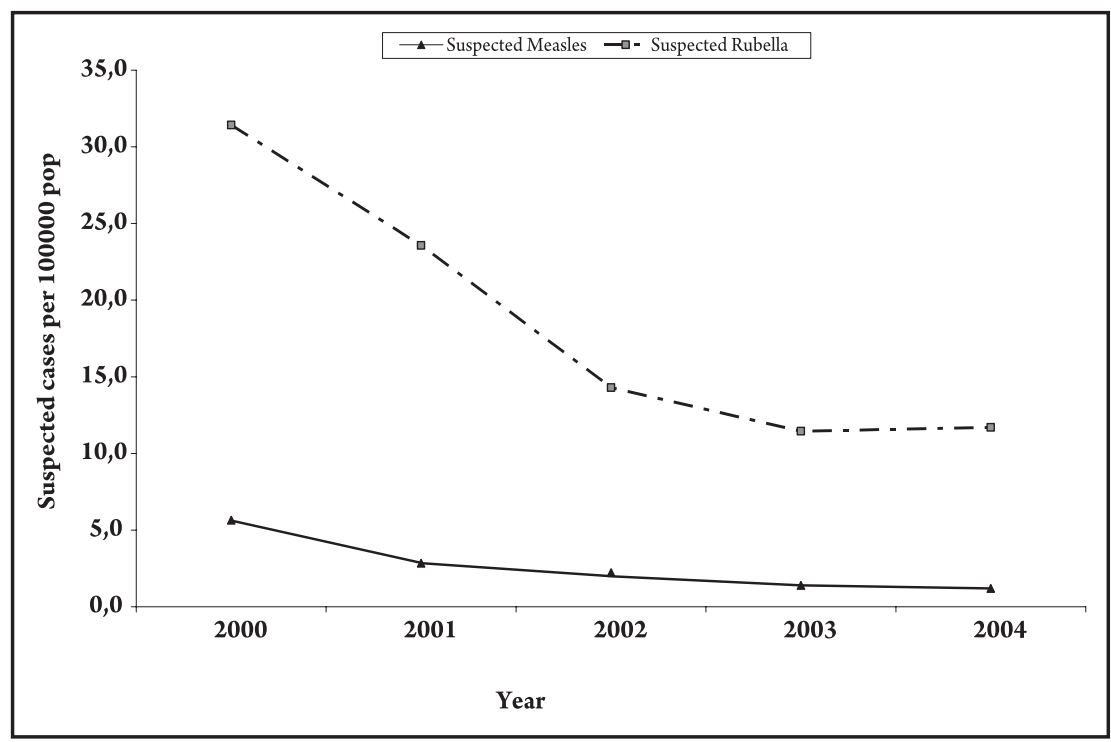

FIGURE 1 - Rate of notifications of suspected measles and rubella cases per 100,000 population, State of São Paulo, 2000-2004.

specimen and were included in this analysis; 99 (21\%) were originally notified as suspected measles and 364 (79\%) as suspected rubella. Blood specimens with measles IgM antibody were collected a median of two days after rash onset (range, 0 to 28 days).

A second blood specimen was obtained from 228 (49\%) of the 463 case patients. The interval between the initial and follow-up specimens was at least 14 days for 171 (75\%) of the 228 episodes (median, 21 days; range 4 to 178 days). In total, 55 (24\%) of the 228 episodes showed seroconversion in measles IgG antibodies; two episodes occurred in children without prior measles vaccination (one imported case of measles in 2000 and one child who received measles vaccine prior to collection of convalescent serum).

During the five-year period, the temporal distribution of measles IgM-positive cases showed seasonal variation, with peaks between September and November, corresponding to months with increased transmission of febrile rash illnesses (Figure 2). In addition, there

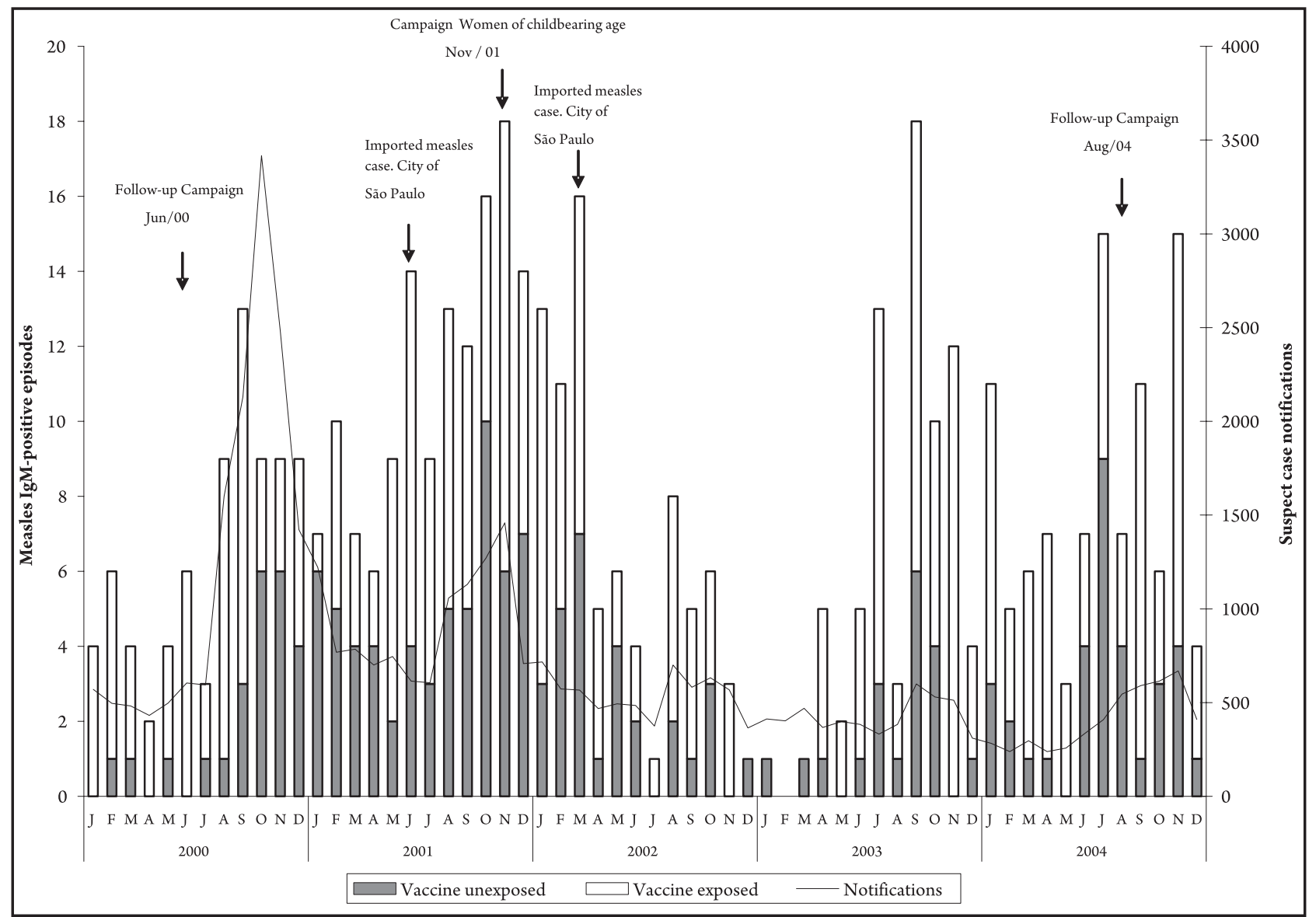

FIGURE 2 - Notified rash illness episodes and anti-measles IgM seropositive episodes according to date of rash illness onset, State of São Paulo, 2000-2004. 
were two peaks of measles IgM-positive cases in 2001 and 2002 following two imported cases of measles from Japan. During these two months, cases were identified in different geographical areas and 10 (53\%) of the $19 \mathrm{IgM}$-positive episodes in unvaccinated individuals tested positive for other viral illnesses. Extensive contact tracing did not identify any secondary cases associated with these importations.

While the majority (56\%) of the measles IgM-positive episodes identified during 2000-2004 resided in the metropolitan region of São Paulo (which accounts for $48 \%$ of the state's population), IgM-positive episodes were also identified in 120 of the 645 municipalities throughout the state, and were not clustered temporally in the same geographical area. In 25 (5\%) of the 463 episodes, the patients identified epidemiological links to other individuals who had acute rash illnesses, but none of these contacts was positive for measles IgM antibodies.

Documentation of measles vaccination was available for 389 (84\%) of the 463 measles IgM-positive cases. In 297 cases, the patients were classified as vaccine-exposed, while 92 had received measles vaccine more than 56 days prior to sample collection. The vaccination history was unknown for 28 individuals, and 46 had not any prior measles vaccination (Table $\mathbf{1}$ ).

The age range of case patients in each measles vaccination history group was consistent with vaccine recommendations: $65 \%$ of the case patients with no prior measles vaccination were younger than 12 months of age, $97 \%$ of case patients with recent vaccination were 9-23 months old, and $92 \%$ of those with past measles vaccination were one year old or over (Table 1). Among measles IgM-positive case patients with no prior measles vaccination, $32 \%$ were 15 years of age or over. The age distribution of vaccine-exposed cases reflected the change in 2003 of the recommended age for measles vaccination from 9 to 12 months: prior to 2003, 52\% of the vaccine-exposed cases occurred among children 9 to 11 months of age versus less than $1 \%$ after 2003.

According to the clinical data for the measles IgM-positive episodes of rash illness, only $59 \%$ of the episodes met the suspected measles case definition (presence of rash, fever and at least one respiratory symptom); the proportion was highest among case patients with no prior measles vaccination (Table 1). Only 15\% of measles IgM-positive episodes met the more specific clinical symptoms of three or more days of rash with preceding fever, with the highest proportion among case patients with no prior vaccination. Four patients, aged four months, 10 months, 23 years and 47 years, were hospitalized; the admission diagnoses were dehydration, scarlatina, acute respiratory infection and pneumonia, respectively.

Among the 463 measles IgM-seropositive episodes, 211 (46\%) had laboratory evidence of infection with other etiologies of rash illness (Table 2). Among the 166 vaccine-unexposed episodes, 109 (66\%) had evidence of another infection: 21 (13\%) with rubella virus, 49 (29\%) with parvovirus B19, 28 (17\%) with HHV-6, five (3\%) with dengue virus, five (3\%) with Epstein Barr virus and one (1\%) with varicella. In addition to measles IgM antibodies, 27 individuals ( $6 \%$ of 463$)$ were IgM-positive for both rubella and HHV-6, three (1\%) for HHV-6 and parvovirus B19 and 12 (3\%) for rubella and parvovirus B19. None of the episodes tested by PCR were positive for both parvovirus and HHV-6.

TABLE 1 - Notified rash illness episodes with positive serological tests for measles IgM antibodies in the absence of documented measles virus transmission, according to measles vaccination history, State of São Paulo, Brazil,2000-2004.

\begin{tabular}{|c|c|c|c|c|}
\hline \multirow{4}{*}{$\begin{array}{l}\text { Characteristics and clinical symptoms } \\
\text { Measles IgM-positive }\end{array}$} & \multirow{4}{*}{$\begin{array}{c}\text { Vaccine-exposed }^{*} \\
\mathbf{n}=\mathbf{2 9 7}\end{array}$} & \multicolumn{3}{|c|}{ Vaccine-unexposed } \\
\hline & & \multirow[t]{2}{*}{$\begin{array}{c}\text { No prior } \\
\text { measles } \\
\text { vaccination } \\
\mathrm{n}=46\end{array}$} & \multirow[t]{2}{*}{$\begin{array}{c}\text { Prior } \\
\text { measles } \\
\text { vaccination }^{+} \\
\mathbf{n}=92\end{array}$} & \multirow[t]{2}{*}{$\begin{array}{c}\text { Unknown } \\
\text { measles } \\
\text { vaccination } \\
\quad \mathbf{n}=\mathbf{2 8}\end{array}$} \\
\hline & & & & \\
\hline & & \multicolumn{3}{|c|}{ Number with characteristic or clinical symptoms (\%) } \\
\hline \multicolumn{5}{|l|}{ Age group } \\
\hline$<9$ months & $3(1)$ & $25(55)$ & $0(-)$ & $0(-)$ \\
\hline 9 to 11 months & $156(52)$ & $5(11)$ & $7(8)$ & $1(3)$ \\
\hline 12 to 23 months & $133(45)$ & $0(-)$ & $16(17)$ & $3(11)$ \\
\hline 2 to 4 years & $2(1)$ & $1(2)$ & $20(22)$ & $0(-)$ \\
\hline 5 to 14 years & $0(-)$ & $0(-)$ & $26(28)$ & $3(11)$ \\
\hline$>=30$ years & $0(-)$ & $7(15)$ & $7(8)$ & $5(18)$ \\
\hline Suspected measles case ${ }^{\ddagger}$ & $179(60)$ & $32(70)$ & $48(52)$ & $13(46)$ \\
\hline Suspected measles case with specific clinical symptoms $\$$ & $38(13)$ & $13(28)$ & $16(17)$ & $4(14)$ \\
\hline Rash & $291(98)$ & $46(100)$ & $89(97)$ & $23(82)$ \\
\hline Days of rash, median (range) $\|$ & $3(0-21)$ & $4(1-14)$ & $4(0-15)$ & $3(0-15)$ \\
\hline Fever & $260(88)$ & $43(93)$ & $72(78)$ & $20(71)$ \\
\hline Days of fever, median (range) $\|$ & $2(0-20)$ & $3(0-30)$ & $2(0-15)$ & $2(0-19)$ \\
\hline Cough & $147(49)$ & $25(54)$ & $32(35)$ & $7(25)$ \\
\hline Conjunctivitis & $44(15)$ & $11(24)$ & $17(18)$ & $8(29)$ \\
\hline Coryza & $150(51)$ & $25(54)$ & $41(45)$ & $8(29)$ \\
\hline Lymphadenopathy & $123(41)$ & $16(35)$ & $36(39)$ & $13(46)$ \\
\hline
\end{tabular}


TABLE 2 - Results from laboratory testing on initial serum specimens for measles, rubella and other viral etiologies of febrile rash illness, among measles IgMseropositive rash illness episodes reported to the measles/rubella surveillance system, State of São Paulo, Brazil, $2000-2004$.

\begin{tabular}{|c|c|c|c|c|c|}
\hline $\begin{array}{l}\text { Laboratory results } \\
\text { Measles IgM-positive }\end{array}$ & $\begin{array}{c}\text { Vaccine-exposed } \\
\mathbf{n}=297\end{array}$ & $\begin{array}{c}\text { No prior measles } \\
\text { vaccination } \\
n=46\end{array}$ & $\begin{array}{l}\text { Prior measles } \\
\text { vaccination }^{+} \\
\quad \mathbf{n}=92\end{array}$ & $\begin{array}{l}\text { Unknown measles } \\
\text { vaccination } \\
\mathbf{n}=\mathbf{2 8}\end{array}$ & $\begin{array}{c}\text { Total } \\
n=463\end{array}$ \\
\hline \multicolumn{6}{|c|}{ number positive/number tested (\%) } \\
\hline Measles $^{\ddagger}$ & $9 / 297(3)$ & $2 / 46(4)$ & $1 / 92(1)$ & $0 / 28(-)$ & $12 / 463(3)$ \\
\hline Indirect IgM ELISA & $257 / 296(87)$ & $37 / 46(80)$ & 73/92 (79) & $25 / 28(90)$ & $392 / 462(85)$ \\
\hline IgM-capture ELISA & $228 / 287(79)$ & $20 / 46(43)$ & $32 / 90(35)$ & $10 / 28(36)$ & $290 / 451(64)$ \\
\hline Both indirect IgM and IgM-capture ELISA & $193 / 286(67)$ & $12 / 46(25)$ & $18 / 91(21)$ & $7 / 28(25)$ & $230 / 451(51)$ \\
\hline IgG ELISA, seroconversion in paired specimens & $51 / 117(44)$ & $2 / 32(6)$ & $2 / 63(3)$ & $0 / 16(-)$ & $55 / 228(24)$ \\
\hline Rubella $^{\ddagger}$ & $4 / 223(2)$ & $9 / 41(22)$ & $2 / 86(2)$ & $10 / 27(37)$ & $25 / 377(7)$ \\
\hline Indirect IgM ELISA & $50 / 112(45)$ & $1 / 12(8)$ & $1 / 33(3)$ & $2 / 6(33)$ & $54 / 163(33)$ \\
\hline IgM-capture ELISA & $9 / 111(8)$ & $4 / 29(14)$ & $2 / 53(4)$ & $10 / 21(48)$ & $25 / 214(12)$ \\
\hline Parvovirus B19 & $35 / 169(21)$ & $7 / 32(22)$ & $37 / 80(46)$ & $5 / 18(28)$ & $84 / 299(28)$ \\
\hline $\operatorname{PCR}(11)$ & $23 / 109(21)$ & $5 / 15(33)$ & 24/61 (39) & $3 / 13(23)$ & $55 / 198(28)$ \\
\hline HHV-6 & $63 / 179(35)$ & $9 / 36(25)$ & $13 / 80(16)$ & $6 / 18(33)$ & $91 / 313(29)$ \\
\hline Immunofluorescence (12) & $59 / 179(33)$ & $9 / 36(24)$ & $12 / 80(15)$ & $8 / 18(44)$ & $88 / 313(28)$ \\
\hline $\operatorname{PCR}(12)$ & $5 / 138(4)$ & $3 / 21(14)$ & $1 / 47(2)$ & $1 / 13(8)$ & $10 / 219(5)$ \\
\hline
\end{tabular}

${ }^{*}$ vaccinated $\leq 56$ days prior to specimen collection, ${ }^{\dagger}$ vaccinated $>56$ days prior to specimen collection, ${ }^{\neq}$totals for laboratory-confirmed measles and rubella episodes include only the episodes with a final classification as measles or rubella based on clinical and epidemiological criteria.

\section{DISCUSSION}

Reviewing the measles IgM-seropositive rash illness episodes provided useful indicators for the sensitivity of the State of São Paulo measles surveillance system following the interruption of endemic measles virus transmission. The overall rate of measles-like illnesses discarded based on laboratory testing was similar to the rates reported from the United States and other countries in the Americas ${ }^{14}$. Approximately $1 \%$ of notified rash illness episodes tested positive for measles IgM antibodies. Active investigation of IgM-positive episodes demonstrated the importance of having a documented vaccination history and additional laboratory testing for case classification. Fewer than $32 \%$ of the episodes met all the criteria for classification as vaccine-associated or false-positive reactions ${ }^{5,6}$, mainly as a result of gaps in the vaccination history or poorly timed specimen collection. Close supervision with follow-up to obtain complete information resulted in better data quality for classification, considering that this is a passive surveillance system ${ }^{15}$. Regular review of IgM-seropositive episodes helped maintain a high level of alert for measles importations, to prevent reintroduction of the measles virus.

As expected based on the high MMR vaccination coverage and periodic follow-up campaigns, the majority of the positive IgM reactions occurred in recently vaccinated individuals. The age distribution of vaccine-exposed cases followed the recommended age of measles vaccination, and immunization campaigns focused on targeted groups. The measles IgM-positive episodes were not clustered geographically and temporally, thus providing evidence that measles transmission was absent during this period. Seasonal peaks of IgM-positive episodes coincided with the winter and spring months, when transmission of rubella, erythema infectiosum and other viral illnesses is highest (including measles in the pre-elimination era $)^{16,17}$. None of the IgM-positive episodes had epidemiological links to the two imported measles cases identified during the period, despite extensive contact tracing ${ }^{1}$. Although we cannot rule out the possibility that individual cases were true measles infections, this review suggested that the surveillance system had adequate sensitivity for identifying measles transmission.

The main limitation of the State of São Paulo measles surveillance was the dependence on serological testing. Timely specimen collection and transportation to the central health department laboratory under appropriate conditions are needed for virus detection. Collection of serum and urine specimens for virus isolation is indicated for measles IgM seropositive episodes ${ }^{10}$, but this results in poorly timed sample collection and low rates of virus isolation ${ }^{18}$. Few specimens tested for measles virus were collected less than six days after rash onset. In the event of measles importation in such a highly vaccinated population, virus detection and characterization is essential for distinguishing wild-type measles infection from vaccine-associated rash illness ${ }^{18,19}$. Alternative diagnostic samples, including saliva, which can be collected on filter paper at the first contact with the healthcare system and later tested for measles virus RNA could improve the timeliness of specimen collection for virus detection ${ }^{20}$.

Without timely specimen collection for virus detection, true measles cases may have been missed. In a highly vaccinated population, individuals may present with clinical manifestations that are less characteristic of classic measles ${ }^{21,22}$, and such cases may not have been notified to the surveillance system. It has been recognized that clinical criteria cannot be used alone to rule out measles infection ${ }^{6}$. However, if measles virus transmission had been occurring, unvaccinated individuals and a small proportion of vaccinated individuals would have been expected to develop classical measles symptoms ${ }^{21,23}$. While individuals with asymptomatic or vaccine-modified measles may be less likely to infect others ${ }^{24,25}$, their role in sustaining low levels of measles virus transmission is unclear ${ }^{21,26,27}$.

The availability of additional laboratory testing supported the findings from the epidemiological investigation. In accordance with the established procedures of the regional measles laboratory network ${ }^{28}$, public health laboratories throughout the State of São Paulo used a single commercial indirect ELISA kit for measles serological assays. The state health department added a second 
serological assay, the IgM-capture ELISA, at the state reference laboratory to aid in the interpretation of positive measles IgM serology. Both tests have high specificity ${ }^{6,8}$ but may differ in their cross-reactivity with other viral causes of rash illness, including rubella, parvovirus and $\mathrm{HHV}-6^{29}$. Use of the IgM-capture ELISA test may reduce false-positive results caused by rheumatoid factor ${ }^{8,9}$. However, concordant results from the two tests were not considered confirmatory. Measles IgG avidity testing on the initial samples may also be helpful for ruling out measles ${ }^{18}$. In addition, collection of a second blood specimen to compare measles IgG titers in serum pairs was useful for discarding episodes as nonmeasles, although $51 \%$ of the serum pairs had an indeterminate result, with IgG titers increasing by less than fourfold. Testing for parvovirus B19 and HHV-6 infection, which are two common causes of rash illness, facilitated the classification of measles IgM-positive episodes. Crossreactivity of measles serological assays with parvovirus B19 and HHV-6 infections has been described ${ }^{29}$. Additional laboratory testing (IgMEIA) on individual episodes identified the dengue virus, Epstein-Barr virus or varicella infection as other potential causes of measles IgM reactivity.

During 2000-2007, significant progress was made towards reducing measles morbidity and mortality worldwide ${ }^{30}$. As long as measles circulates, Brazil remains at risk of importations. Brazil receives more than five million visitors from other countries and more than one million Brazilians travel internationally, each year ${ }^{31}$. Notably, in 2008, Brazil remained free from importation-associated measles outbreaks that affected other countries ${ }^{32,33}$. However, the surveillance system needs to be prepared to rapidly identify and respond to imported measles, in order to limit its spread. Improvements in early specimen collection for virus isolation are needed, so that possible sources of imported cases can be identified. Maintaining political will in the absence of disease transmission requires a high level of confidence in the surveillance system.

\section{ACKNOWLEDGMENTS}

The authors thank the researchers in the Measles and Viral Rash Illness Laboratory of the Virology Department, Adolfo Lutz Institute, São Paulo, for the laboratory investigations of cases; and the epidemiological surveillance staff of the state and municipal health departments of the State of São Paulo for the clinical and epidemiological investigation of these cases.

\section{CONFLICT OF INTEREST}

The authors declare that there is no conflict of interest.

\section{REFERENCES}

1. Prevots DR, Parise MS, Segatto TCV, Siqueira MM, Santos ED, Ganter B, et al Interruption of measles transmission in Brazil, 2000-2001. J Infect Dis 2003; 187 (suppl 1):S111-120.

2. Quadros CA. Can measles be eradicated globally? Bull WHO 2004; 82:134-138

3. Brasil. Ministério da Saúde. Guia de vigilância epidemiológica da Secretaria de Vigilância em Saúde: sarampo, 6 ed. Brasília. Ministério da Saúde; 2005.

4. Pan American Health Organization. Measles elimination: field guide, $2^{\text {nd }}$ ed. Washington DC: Pan American Health Organization; 2005.

5. Vicari AS, Dietz V, Bellini WJ, Icenogle J, Castillo-Solorzano C. Interpretation of measles and rubella serology. In: Andrus J, de Quadros C, editors. Recent advances in immunization, $2^{\text {nd }}$ ed. Washington DC: Pan American Health Organization; 2006. p. 80-98.

6. Dietz V, Rota J, Izurieta $\mathrm{H}$, Carrasco P, Bellini W. The laboratory confirmation of suspected measles cases in settings of low measles transmission: conclusions from the experience in the Americas. Bull WHO 2004; 82:852-857.
7. Pan American Health Organization. Measles case classification: frequent dilemmas in the field. EPI Newsletter. 2001; 23:4-5.

8. Erdman DD,AndersonLJ,Adams DR, StewartJA, MarkowitzLE, BelliniWJ.Evaluation of monoclonal antibody-based capture enzyme immunoassays for detection of specific antibodies to measles virus. J Clin Microbiol 1991; 29:1466-1471.

9. Hummel KB, Erdman DD, Heath J, Bellini WJ. Baculovirus expression of the nucleoprotein gene of measles virus and utility of the recombinant protein in diagnostic enzyme immunoassays. J Clin Microbiol 1992; 30:2874-2880.

10. São Paulo. Secretaria Estadual de Saúde de São Paulo. Guia de vigilância para a erradicação do sarampo, controle da rubéola e da síndrome da rubéola congênita. São Paulo, Brasil: Secretaria Estadual de Saúde de São Paulo; 2002.

11. Durigon EL, Erdman DD, Gary GW, Pallansch MA, Torok TJ, Anderson LJ Multiple primer pairs for polymerase chain reaction (PCR) amplification of human parvovirus B19 DNA. J Virol Methods 1993; 44:155-165.

12. Yalcin S, Yamanishi K. Human herpesvirus 6 (HHV-6). In: Lennette EH, Schmidt NJ, editors. Diagnostic procedures for viral, rickettsial and chlamydial infections, $7^{\text {th }}$ ed. Washington DC: American Public Health Association; 1995. p. 397-405.

13. Helfand RF, Kebede S, Gary HE, Beyene H, Bellini WJ. Timing of development of measles-specific immunoglobulin $\mathrm{M}$ and $\mathrm{G}$ after primary measles vaccination. Clin Diagn Lab Immunol 1999; 6:178-180.

14. Harpaz R, Papania MJ. Can a minimum rate of investigation of measleslike illnesses serve as a standard for evaluating measles surveillance? J Infect Dis 2004; 189 (suppl 1):S204-209.

15. BarrosENC, Silva EM. Epidemiologic surveillance of measles and rubella in Campinas (SP), Brazil: the reliability of the data. Pan Am J Public Health 2006; 19:172-178.

16. Moss WJ, Ota MO. Measles. In: Nelson KE, Williams CM, editors. Infectious Disease Epidemiology. Theory and Practice. $2^{\text {nd }}$ ed. Boston: Jones and Bartlett; 2007. p. 601-636.

17. Young NS, Brown KE. Parvovirus B19. New Engl J Med 2004; 350:586-597.

18. Bellini WJ, Helfand RF. The challenges and strategies for laboratory diagnosis of measles in an international setting. J Infect Dis 2003; 187 (suppl 1):S283-290.

19. Hyde TB, Nandy R, Hickman CJ, Langidrik JR, Strebel PM, Papania MJ, et al Laboratory confirmation of measles in elimination settings: experience from the Republic of the Marshall Islands, 2003. Bull WHO 2009; 87:93-98.

20. Recommendations from an ad hoc Meeting of the WHO Measles and Rubella Laboratory Network (LabNet) on use of alternative diagnostic samples for measles and rubella surveillance. MMWR 2008; 57:657-660.

21. Helfand RF, Kim DK, Gary HE, Edwards GL, Bisson GP, Papania MJ et al Nonclassic measles infections in an immune population exposed to measles during a college bus trip. J Med Virol 1998; 56:337-341.

22. Vardas E, Kreis S. Isolation of measles virus from a naturally-immune, asymptomatically re-infected individual. J Clin Virol 1999; 13:173-179.

23. Aaby P, Bukh J, Leerhoy J, Lisse IM, Mordhorst CH, Pedersen IR. Vaccinated children get milder measles infection: a community study from Guinea-Bissau. J Infect Dis 1986; 154:858-863.

24. Rota PA, Khan AS, Durigon E, Yuran T, Villamarzo YS, Bellini WJ. Detection of measles virus RNA in urine specimens from vaccine recipients. J Clin Microbiol 1995 ; 33:2485-2488.

25. Whittle HC, Aaby P, Samb B, Jensen H, Bennett J, Simondon F. Effect of subclinical infection on maintaining immunity against measles in vaccinated children in West Africa. Lancet 1999; 353:98-102.

26. Lievano FA, Papania MJ, Helfand RF, Harpaz R, Walls L, Katz RS, et al. Lack of evidence of measles virus shedding in people with inapparent measles virus infections. J Infect Dis 2004; 189 (suppl 1):S165-170.

27. Pannuti CS, Morello RJ, Moraes JC, Curti SP, Afonso AMS, Camargo MCC Identification of primary and secondary measles vaccine failures by measurement of immunoglobulin G avidity in measles cases during the 1997 São Paulo epidemic. Clin Diagn Lab Immunol 2004;11:119-122.

28. Venczel L, Rota J, Dietz V, Morris-Glasgow V, Siqueira M, Quirogz E, et al. The Measles Laboratory Network in the region of the Americas. J Infect Dis 2003 ; 187 (suppl 1):S140-145.

29. Thomas HI, Barrett E, Hesketh LM, Wynne A, Morgan-Capner P. Simultaneous IgM reactivity by EIA against more than one virus in measles, parvovirus B19 and rubella infection. J Clin Virol 1999;14:107-118.

30. Progress in global measles control and mortality reduction, 2000-2007. MMWR 2008; 57:1303-1306.

31. Ministério do Turismo. [Internet] [citado em 29 de setembro de 2009]; Disponível em: http://www.turismo.gov.br

32. Centers for Disease Control and Prevention. Update: measles-United States, January-July 2008. MMWR 2008; 57:893-896.

33. Muscat M, Bang H, Wohlfahrt J, Glismann S, Molbak K. Measles in Europe: an epidemiological assessment. Lancet 2009; 373:383-389. 